\title{
反射性交感神経性萎縮症に対する外科治療 一特に交感神経切除について一
}

\author{
愛媛大学第 1 外科 \\ 大西克幸八杉巧嶌原康行 小林展章
}

当科で過去 16 年間に経験した反射性交感神経性萎縮症およびその関連疾患 48 例に対して施行した交感 神経ブロックと交感神経切除術の治療成績について検討した。痛みが半分以下になったものを有効として有 効率をみると, 星状神経節ブロック約 $33 \%$, 上胸部交感神経切除 $75 \%$, 腰部交感神経ブロック $60 \%$, 腰部 交感神経切除 $80 \%$ であった。このうち Kunz 神経経路の交感神経遮断を目的に行った第 2,3 肋間神経のア ルコールブロックを追加した内視鏡下上胸部交感神経切除を施行した 4 例では, 観察期間は 1 年余りである が交感神経活動の再燃を認めていない。また, 交叉神経切除追加腰部交感神経切除では, 有効率は $91 \%$ であ った。痛みに対する総合有効率は, 交感神経ブロックを中心とする保存的治療が約 $52 \%$, 交感神経切除を中 心とする外科的治療が約 $78 \%$ であった。本症の治療上のポイントとして, 患部支配の交感神経遮断を可能な 限り実施することが重要であると考えられた。

索引用語 : 反射性交感神経性萎縮症, 内視鏡下上胸部交感神経切除術, 腰部交感神経切除術, 交叉神経

\section{はじめに}

反射性交感神経性萎縮症 (reflex sympathetic dystrophy, 以下 RSD と略す) は, ペインクリニ ックで扱う疾患のなかでは, 治療困難な疾患の 1 つであり，特徵のある焼けつくような痛みととも に, 交感神経系の過緊張, 知覚異常, 機能異常が 認められる病態を総称した疾患名である1。

本稿では，われわれが過去 16 年間に経験した $\mathrm{RSD}$ およびRSD関連疾患 48 例に対して施行し た交感神経ブロックと交感神経切除の治療成績に ついて述へ，また新しい工夫を加えた交感神経切 除術について述べたい。

\section{対象および方法}

\section{1. 対象と背景}

1978 年 1 月より 1993 年 12 月までにわれわれ が経験した RSD および RSD 関連疾患 48 例を対 象とした。性別は男性 29 例, 女性 19 例, 年㱓は 17 歳から 80 歳, 平均 48.9 歳であった。そのうち わけは, International Association for Study of Pain (IASP) の定義6)にしたがって分類すると
RSD 41 例, causalgia 2 例, deafferentation pain syndrome 5 例であった。発症部位は上肢が 18 例 20 肢, 下肢が 30 例 31 肢であった。

〈発症原因〉（図 1)

挫傷, 捻挫(足関節), 圧挫, 刺創など外傷に起 因するものが 12 例 (25\%) と最も多く，次いで手 術が発症に関与しているもの 10 例 (21\%), 以下 post disease (血管炎, 股関節炎, 胸郭出口症候群 など) 9 例 (18\%), 骨折 6 例 (12\%), 切断 5 例 (10 $\%$, 頸部捻挫 3 例 (6\%), 抜歯と注射針それぞれ 1 例 $(2 \%)$, 不明 2 例 $(4 \%)$ など種々の原因が存 在した。

\section{〈疼痛部位の知覚状態〉}

知覚過敏を呈していたものが 21 例 (43\%) と最 も多く, 次に知覚異常を認めなかった正常知覚の ものが 11 例 $(23 \%)$, 以下知覚鈍麻 8 例 (16\%), 知覚鈍麻と痛覚過敏が同じ部位に混在していたも の 6 例 $(12 \%)$, 無知覚性疼痛 3 例 $(6 \%)$ であっ た。

〈随伴症状〉

患肢の随伴症状としては, 冷感, チアノーゼ, 皮膚温低下, 浮腫などの循環障害が認められたも 
の加 41 例，登汗異常が 27 例，爪瓜，发膚，筋，骨 などの委縮がみられたものが24例であった。 〈受傷から発症までの期間〉

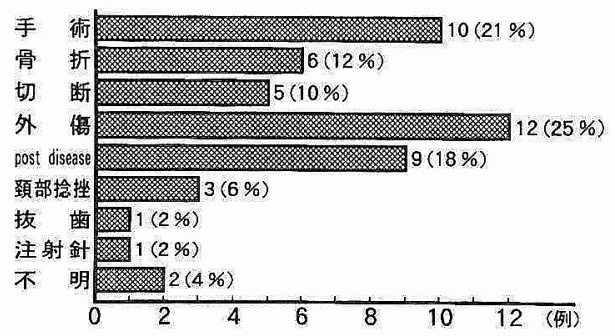

図 1 発症原因

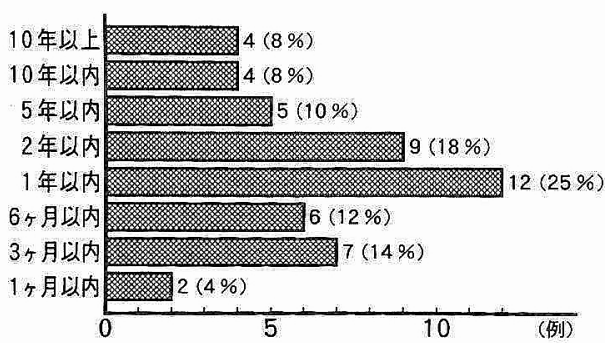

図 2 発症から初診までの期間

\begin{tabular}{|c|c|c|c|}
\hline 治療法 & 上肢 & 下 肢 & 計 \\
\hline \multicolumn{4}{|l|}{$<$ 保存的治療 $>$} \\
\hline 星状神経節ブロック (単独) & & & 6 \\
\hline 要部交感神経ブロック (単独) & & $15(16)$ & 15 \\
\hline \begin{tabular}{|ll} 
便膜外プロック (重複) \\
\end{tabular} & प्ब6 & menter 4 & 10 \\
\hline 体性神経ブロック (重複) & 滀 6 & 10 & 16 \\
\hline $\begin{array}{ll}\text { TENS } & \text { (重複) } \\
\end{array}$ & 112 & श्राप्योग & 31 \\
\hline 許 & 30 & 48 & 78 \\
\hline <外科的治療 $>$ & & & \\
\hline 上胸部交感神経切除 & & & \\
\hline 腋䆚経胸法 & 2मायु 3 & & 3 \\
\hline 内視鏡下手郝 & ग(11) & & 9 \\
\hline 偠部交感神経切除 & & & \\
\hline 標淮的切除 & & गायाओ 4 & 4 \\
\hline 交叉神経遮断追加切除 & & & 11 \\
\hline Smithwickの手街 & & 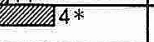 & 4 \\
\hline 断端神経切除 & & 210 $3 * *$ & 3 \\
\hline 計 & $12(14)$ & 22 & 34 \\
\hline
\end{tabular}

図 3 治 療 法
受傷あるいは RSDの誘因となった病態の発 生)から RSD 発症までの期間をみると，受傷直後 からのものが 18 例 $(38 \%) ， 1$ 年以上経過して発症 したものが 13 例 $(27 \%), 1$ 力月以内，3力月以内, 6 力月以内の発症がそれぞれ6例 $(12 \%)$ であ た。受傷後 1 年以上を経て発症したものは，はと んどの症例で受傷後から RSD 発症までに経度の 冷感やシビレ感を自覚しており，症状が次第に増 悪したものである。

〈発症から初詮までの期間〉（図 2)

発症から当科受㟝までの期間をみると，6力月 以内の受診は 15 例 $(30 \%)$ と少なく，6力月以上 経過したものが 34 例 $(70 \%)$ にび，1 年以上経 過しているものも22 例 $(44 \%)$ 欢られた。

\section{2. 治療方法}

これらの症例に用いた保存的治療と外科的治療 の方法を羅患部位別に図 3 に示寸。保存的治療と しては星状神経節ブロック，腰部交感神経ブロッ

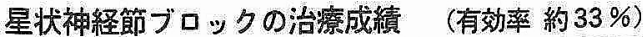

\begin{tabular}{|c|c|c|c|c|}
\hline pain relief score & 定例政 & 勃果 & 遈例龉 & 睡眠の程虚 \\
\hline $10 \rightarrow 0$ & 0 & 著効 & 0 & 痛みなく眠れる \\
\hline $10 \rightarrow 1 \sim 5$ & 2 & 有效 & 4 & 痛いが眠れる \\
\hline $10 \rightarrow 6 \sim 9$ & 4 & やや有勃 & 2 & 薬物使用で眠れる \\
\hline $10 \rightarrow 10$ & & 俩效 & 0 & 痛くて眠れない \\
\hline
\end{tabular}

上胸部交感神経切除の成續

(有效率 $75 \%$ )

\begin{tabular}{|c|c|c|c|c|}
\hline pain relief score & 症例数 & 效果 & 昰例数 & 睡貤の程度 \\
\hline $10 \rightarrow 0$ & 3 & 篁效 & 3 & 痛みなく眠んる \\
\hline $10 \rightarrow 1 \sim 5$ & 6 & 有勃 & 8 & 痛いが眠れる \\
\hline $10 \rightarrow 6 \sim 9$ & $\frac{5}{2}$ & 中心有勃 & 1 & 䔲物使用で眠れる \\
\hline $10 \rightarrow 10$ & 1 & 無勃 & 0 & 痛くて眠れない \\
\hline
\end{tabular}

循環障害再器・異常発汗 : 2 例（約 $17 \%$ )

腰部交感神縁ブロックの治療成續（有效率 $60 \%$ ）

\begin{tabular}{|c|c|c|c|c|}
\hline pain relief score & 例跤 & 効果 & 症例政 & 睡眠の程度 \\
\hline $10 \rightarrow 0$ & 2 & 擎効 & 5 & 洏みなく眠れる \\
\hline $10 \rightarrow 1 \sim 5$ & 7 & 有勃 & 4 & 痛いが眠れる \\
\hline $10 \rightarrow 6 \sim 9$ & 6 & 也吅有效 & 6 & 新物使用で眠れる \\
\hline $10 \rightarrow 10$ & 0 & 無効 & 0 & 痛くて眠れない \\
\hline
\end{tabular}

腰部交感神経切除の治澺成續

(有效率 $80 \%$ )

\begin{tabular}{|c|c|c|c|c|}
\hline pain relief score & 症例数 & 效果 & 定矨数 & 睡眠の程度 \\
\hline $10 \rightarrow 0$ & 3 & 箸勃 & 4 & 衤みなく眠れる \\
\hline $10 \rightarrow 1 \sim 5$ & 9 & 有效 & 9 & 痛いが眠れる \\
\hline $10 \rightarrow 6 \sim 9$ & 3 & 中や有效 & 2 & 薬物使用で眠れる \\
\hline $10 \rightarrow 10$ & $\overline{0}$ & 無効 & 0 & 痛くて眠れない \\
\hline
\end{tabular}

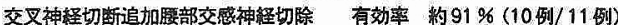

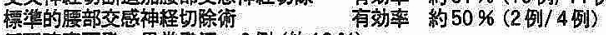

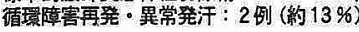

図 4 治療法別の成績 
ク, 硬膜外ブロック, 体性神経ブロック, transcutaneous electrical nerve stimulation （TENS）を用い, 外科的治療としては上胸部交感 神経切除, 腰部交感神経切除 (交叉神経切断追加 手術を含む), Smithwick の手術, 断端神経切除を 用いたが，すべての症例で交感神経ブロックある いは交感神経切除を併用した。

交感神経ブロックを行った群と交感神経切除を 行った群の治療成績を検討し，また従来の標準的 腰部交感神経切除術と交叉神経切断追加術式の治 療成績について検討した。

痛みの評価は, 治療前の痛みを 10 とし, 現在い くつになったかという 10 段階による pain relief score を用いた。10が 0 になったものを著効，10 が 1 から 5 になったものを有効, 10 が 6 から 9 に なったものをやや有効, 10 から変わらないものを 不変と評価した。治療後の睡眠の程度は, 痛みな く眠れる, 痛いが眠れる, 薬物を使用してなんと か眠れる, 痛くて眠れないの 4 段階に分けて評価 した。今回は交感神経ブロックあるいは交感神経 切除を施行した時点で痛みの程度を評価した。

なお, 統計学的検討は $x^{2}$ 検定を用い, 危険率 5 \% 以下を有意と判定した。

\section{結果（図 4)}

\section{1.上肢の病変に対する治療成績}

治療終了時の pain relief score を見ると星状神 経節ブロックには完全除痛例はなく，有効以上の 全体に占める割合を有効率で表わすと約 $33 \%(6$ 例中 2 例）であり，薬物使用なしで眠れたものが 4 例（約 67\%）であった。上胸部交感神経切除で は完全除痛が 3 例, 痛みに対する有効率は $75 \%$ （12 例中 9 例）であり，薬物使用なしで眠れたもの 11 例（約 92\%）であった。星状神経節ブロックと 上胸部交感神経切除の両群間に有意差はなかった $(\mathrm{p}<0.1)$ 。

\section{2. 下肢の病変に対する治療成績}

腰部交感神経ブロックでは完全除痛が 2 例, 痛 みに対する有効率は $60 \%$ (15 例中 9 例）であり， 薬物使用なしで眠れたものが 9 例 $(60 \%)$ であっ た。腰部交感神経切除では完全除痛が 3 例であり, 痛みに対する有効率は $80 \%$ （15例中 12 例）であ
つた。このうち, 標準的腰部交感神経切除の有効 率は 50\% (4 例中 2 例), 交叉神経切断追加腰部交 感神経切除の有効率は約 $91 \%$ （11 例中 10 例）で あった。薬物使用なしで眠れたものが 13 例(約 87 \%)であった。腰部交感神経ブロックと腰部交感 神経腰除の両群間に有意差はなかった。また, 標 準的腰部交感神経切除と交叉神経切断追加腰部交 感神経切除の両群間に有意差はなかった $(\mathrm{p}<$ $0.1)$ 。

\section{3. 保存的治療と外科的治療の治療成績}

痛みに対する総合有効率は，交感神経ブロック を中心とする保存的治療が約 $52 \%$, 交感神経切除 を中心とする外科的治療が約 78\% であったが, 両 群間に有意差はなかった $(\mathrm{p}<0.1)$ 。

\section{考 察}

RSD には, 発症早期のブロック療法が, 予防お よび治療上きわめて効果的であるといわれてお ク5), トリガーポイントへの局注や交感神経ブロ ックが一般に用いられている。特に交感神経ブロ ックは，今日でも最も支持されている治療法であ $\eta^{8)}$, 局所麻酔剂や神経破壊剂によるブロック, あ

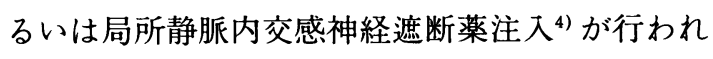
ている。

一方，日常臨床においてはブロック療法が奏効 しない症例も少なからず経験するところである。 このような症例に対する治療の strategyを検討 する場合には，その病態における交感神経系が関 与する末梢機序 ${ }^{1114)}$ あるいは交感神経の解剖学 的変異を考慮する必要がある。かつてはエファプ 又伝達 ${ }^{3)}$ が RSD の中心的な役割を演じていると 考えられていたが, 近年, ノルアドレナリンによ つて媒介される化学的 cross-talk ${ }^{1114)}$ が注目さ れている。ノルアドレナリンが交感神経節後線維 から放出されると $\alpha$ 受容体をもつようになった 感覚線維が反応するため痛みが持続するという考 え方である。これに従えば, 除痛を得るためには 完全な交感神経遮断が必須となる。

また，ヒトの四肢を支配する交感神経系には解 剖学的変異が高頻度にみられ, 上肢では Kunz 神 経による側副路 ${ }^{13)}$, 下肢では交叉神経を介する反 
a )

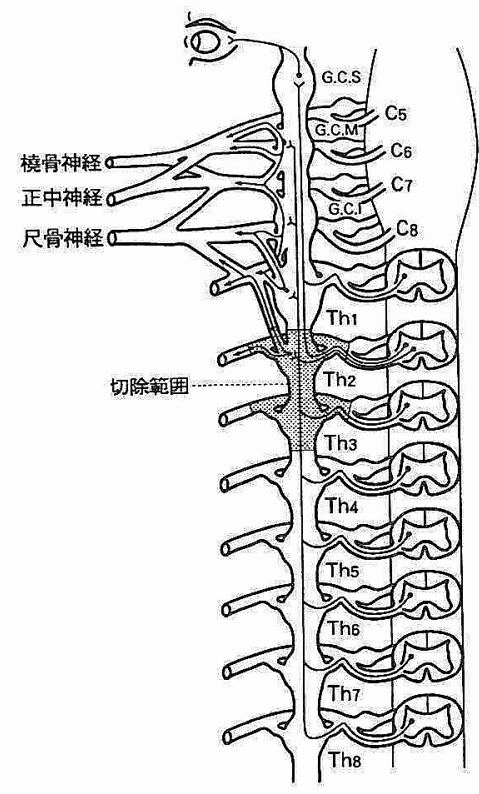

b )

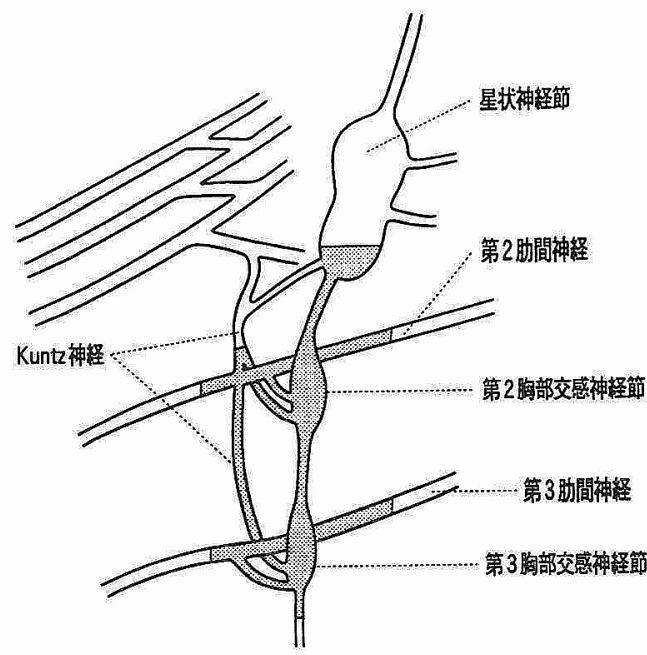

切除範囲

図 5 a) 上胸部交感神経切除の切除範囲

b) 解剖学的変異による Kuntz 神経

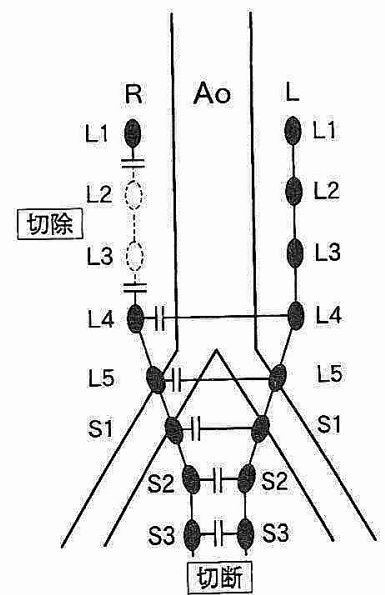

図 6 交叉神経切断追加腰部交感神経切除の手術 シェーマ

対側交感神経幹からの支配27)10)，側行枝および異 所性神経節が存在する。従って, 通常の交感神経 節ブロックを行っても不完全な交感神経遮断を余 儀なくされることになり，解剖学的変異を考慮し た交感神経遮断手技の開発が治療上の重要なポイ ントになると考えられる。
われわれはこれらの間題点の対策として，よ り完全な交感神経遮断を目指して交感神経切除術 に新しい工夫や改良を加えてきた。上肢の病変に 対しては，1991 年 8 月以降，アプローチを腋窩経 胸膜法から内視鏡下手術に変更し，現在は第 1 胸 部交感神経䬣下部 $1 / 3$ および第 2,3 胸部交感神経 節の切除に加えて，第 $2 ， 3$ 肋間神経をアルコ一ル でフッッすることにより Kunz 神経遮断を実施 している（図5）。本法は，手術手技に習熟すれば 術野が極めて鮮明なため，繊細な神経処理などの 操作ができる。また，出血はほとんどみられず， 手術時間も腋窝経胸膜法の約平分，胸腔ドレーン 留置の必要もなく, 術後 1 週間で退院が可能であ る。下肢の病変に対しては, 1984 年以降, 標準的 切除範囲である第 2,3 腰部交感神経節切除に加之 乙第 4 腰部交感神経節加ら第 3 仙部交感神経節間 の交叉神経およびその間に入る側行枝を含めて追 加切断を行っている（図 6)。この術式は仙骨前面 の前縦靶带に沿って尾側に向かって剥離するため 慎重な操作が必要であるが，腸腰静脈を結紮切離 すると仙部の交感神経幹は十分に展開される。 
交感神経ブロックと交感神経切除の治療成績を 有効率でみると，上肢および下肢のいずれの病変 に対しても交感神経除切のほうが有効率は高かっ たが，两群間に有意差は認められなかった。

星状神経節ブロックには Horner 症候群の合併 症を避けるため局所麻酔剂を使用したが，ブロッ ク直後の一時的な効果は見られるものの持続性に 難があり，ブロックの中止により症状の再燃をき たした症例が多かった。上胸部交感神経切除はブ ロックの効果不良例に対して行ったが，標準的切 除範囲では循環障害再発が 25\%（8 例中 2 例）に みられたため, 現在は側副路となる Kunz 神経遮 断を追加している。観察期間は 1 年余りであるが 実施した 4 例については交感神経活動の再燃を認 めていない。星状神経節ブロックと上胸部交感神 経切除の両群間の治療成績に有意差はなく，また 標準的切除と Kunz 神経遮断追加術式の両群間の 治療成績にも有意差はなかった。しかし, Kunz 神 経遮断追加術式は, 理論的にはより確実な交感神 経遮断が得られると考えられ，今後も症例を重ね てゆきたい。

腰部交感神経幹の解剖学的構築からみれば, 交 感神経遮断を行った部位の尾側に存在する交叉神 経等を介する支配が残存することになる。第 2 , 第 3 腰部交感神経節のみの遮断を目的とする腰部交 感神経ブロックの有効率は 60\%（15 例中 9 例）, 標準的腰部交感神経切除の有効率は 50\%（4 例中 2 例)であったのに対して, 交叉神経切断追加例の 有効率は $91 \%$ （11 例中 10 例）であったことから 推測すれば, 症例を重ねてゆけば交叉神経の追加 切断は,より確実な交感神経遮断術式として期待 できるものと思われる。ただし，今回の検討では， 腰部交感神経ブロックと腰部交感神経切除の両群 間に有意差はなく，また標準的腰部交感神経切除 と交叉神経切断追加腰部交感神経切除の両群間に は有意差はなかった $(\mathrm{p}<0.1)$ 。

本症受傷から発症までの期間は, 直後のものか ら 3 年 8 力月に及び，また発症から初診までの期 間は最短 3 週, 最長 35 年の長期に瓦るものがあっ た。これらの期間の長短と治療による痛みの減少 度には特に一定の傾向はなく, 小川ら ${ }^{9)}$ の報告と 同様の結果であったが，後者の期間でみると有効
例は最長 16 年であり発症から年月を経た症例で も交感神経遮断は有意義であると考之られた。

本症における重症度は, 発症の起点となった原 疾患の状態やその病期 ${ }^{12)} に よ り$ 異なるが，少なく とも原疾患が改善されていない場合, あるいは萎 縮期に達している場合には交感神経遮断だけでは 治療効果が不十分な症例が多かった。

\section{おわりに}

以上，RSD および RSD 関連疾患の痛みの治療 に関し，交感神経ブロックと交感神経切除の治療 成績を中心に述べた。これらの疾患は非癌性慢性 疼痛のうち最も難解な疾病であり, 病態の発生機 序は仮説の段階に止まっている。今後の研究が待 たれるが，適時に適切な治療を施すことが極めて 重要であり，また患者を苦痛の底から助け出すあ らゆる努力を意ることがあってはならない。

\section{参考文献}

1) Bonica JJ : The management of pain, Lea and Febiger, Philadelphia, 1953, 913-978

2) Cowley RA, Yeager GH : Anatomic observation on the lumbar sympathetic nervous system. Surgery 25:880-890, 1949

3) Drucker WR, Hybay CA, Holden WD, et al. : Pathogenesis of posttraumatic sympathetic dystrophy. Amer. J. Surg. 97 : 454-465, 1959

4) Hannington-Kiff JG : Relief of Sudeck's atrophy by regional intravenous guanethidine. Lanset 1: 1132-1133, 1977

5）兵藤正義, 田中 衛, 肥後源市, 他：反射性交感 神経性萎縮症. 外科治療 $19: 833-839,1968$

6) IASP Subcommittee on Taxonomy, Classification of chronic pain. Pain Suppl 3: 1-226, 1986

7）松島 茂: 人類の腰仙部交感神経幹の解剖学的 知見補遺. 満州医 $10 ： 507-557,1929$

8）宮崎東洋, 徳田秀光: 反射性交感神経性萎縮 症; 考之方および治療法の変遷. ペインクリニ ック $10: 575-580,1989$

9）小川節郎, 佐伯 茂, 鈴木 太：反射性交感神経 性萎縮症；神経ブロックの効果を中心に. ペイ ンクリニック $10: 581-589,1989$ 


\section{日本外科系連合学会誌 第 20 巻第 2 号}

10）大西克幸：ネコ後肢の皮膚，筋，動脈の交感神経 支配に関する神経解剖学的研究。自律神経 28 ： 298-312. 1991

11) Perl ER: Alternations in the responsiveness of cutanious nociceptors. Sensitization by noxious stimuli and the induction of adrenergic responsiveness by nerve injury. In : W. D. Wills (ed.) Hyperalgesia and Allodinia. Raven Press, New York, 1992, 59-79
12) Schwarzman RJ, McLellan TL: Reflex sympathetic dystrophy. Arch. Neurol. 44 : 555561, 1987

13）恒川謙吾：現代外科手術学体系 (第 2 巻 B), 中 山書店, 東京, p. 252-319, 1981

14) Wall PD, Gutnick $M$ : Ongoing activity in peripheral nerves: The physiology and phamacology of impulses originating from a neuroma. Exp Neurol 43: 580-593, 1974 